\title{
Validity and Reliability Analyses for the Development of Urimal Test of Articulation and Phonology-2
}

\author{
Young Tae Kim ${ }^{a}$, Heeyoung Park ${ }^{\mathrm{a}}$, Jin Kyong Kang, ${ }^{\mathrm{a}}$, Jung A Kimª, Moon Ja Shin' ${ }^{\mathrm{b}}$, Soo-Jin Kim ${ }^{\mathrm{c}}$, Ji-Wan Ha ${ }^{\mathrm{d}}$ \\ ${ }^{a}$ Department of Communication Disorders, Ewha Womans University, Seoul, Korea \\ ${ }^{b}$ Department of Speech Language Pathology, Chosun University, Gwangju, Korea \\ 'Department of Communication Disorders, Korea Nazarene University, Cheonan, Korea \\ ${ }^{d}$ Department of Speech Pathology, Daegu University, Gyeongsan, Korea
}

Correspondence: Young Tae Kim, PhD

Department of Communication Disorders, Ewha Womans University, 52 Ewhayeodae-gil, Seodaemun-gu, Seoul 03760, Korea

Tel: +82-2-3277-2120

Fax: +82-2-3277-2122

E-mail: youngtae@ewha.ac.kr

Received: October 6, 2018

Revised: November 19, 2018

Accepted: November 19, 2018

\begin{abstract}
Objectives: This study is to investigate the validity and the reliability of Urimal Test of Articulation and Phonology-2 (U-TAP2). U-TAP2 has been developed to assess 2- to 7-year-old children's phonological ability. U-TAP2 consists of two levels: word and sentence. Methods: Six hundred and sixteen children participated in this study. For content validity, a 5-scorescale was used for each item and speech-language pathologists served as assessors. The correlations among measured variables-U-TAP percentage of correct consonants (PCC), $P C C$, phonological mean length of utterance (PMLU), proportion of whole-word proximity (PWP), proportion of whole-word correctness (PWC) - were analyzed for construct validity. Results: The results were as follows. For content validity, the mean scores of word and sentence levels were 4.52 and 4.49 , respectively. For concurrent validity, the correlation coefficient between the results of the U-TAP2 and the U-TAP was calculated. It also showed significant correlation. PCCs of word and sentence levels were significantly different by age. The internal consistency (Cronbach's a) was greater than .9 and the split-half reliability and test-retest reliability were also significantly high. Conclusion: The results of this study indicate that the U-TAP2 is a valid and reliable assessment tool for children's phonological ability and that it can provide useful information in analyzing the developmental characteristics of phonological abilities and in intervening the children who have phonological problems.
\end{abstract}

Keywords: Phonology and articulation assessment, U-TAP2, Validity, Reliability
우리말 조음·음운평가(Urimal-Test of Articulation and Phonology, U-TAP; Kim \& Shin, 2004)는 30개의 낱말 그림을 보고 이 름을 말하는 과정을 통해 단어의 어절 내 어두초성, 어중초성, 어말 종성으로 이루어진 43 개의 자음과 10 개의 단모음을 검사하여 자 음정확도 및 모음정확도를 산출할 수 있게 제작된 검사도구이다. U-TAP은 서울과 대구 지역에서 만 2세부터 6세까지의 아동을 대 상으로 말소리 산출능력을 평가하여 발달 규준을 제시하였으며, 단어 수준뿐만 아니라 동일한 낱말에 대하여 16 개의 문장 맥락에 서도 검사할 수 있도록 제작되었다. 또한 발달적 오류패턴에 기반
한 간략 음운변동 분석이 가능하다. U-TAP은 비교적 짧은 시간 안 에 검사실시가 가능하며 낱말분석표와 문장분석표의 두 가지 상 황에서의 아동의 발음을 쉽게 비교할 수 있게 고안되었다. 또한 표 준화된 규준을 제공하기 때문에 아동이 습득한 개별음소분석과 음소정확도, 음운변동 출현율을 또래와 비교할 수 있게 하였다 (Kim \& Shin, 2004; Kim, Shin, \& Kim, 2014). 이러한 장점으로 인 하여 U-TAP은 아동과 치료사에게 가장 쉽고 간단하다는 평가를 받으며 약 10 여 년 이상 임상현장에서 널리 사용되고 있다(Kim MJ, 2016; Kim \& Lee, 2011). 
그러나 U-TAP이 출간된 후 수년이 지남으로써 변화하는 말·언 어 환경과 새롭게 축적되는 말소리 발달과 장애 분야의 연구결과 들을 반영할 수 있도록 검사도구의 개정 및 개발의 필요성이 대두 되었다. 첫째, 약 10 여 년의 시간이 흐르면서 달라진 풍속을 고려하 여 명명일치도, 그림타당도 등을 고려한 현실적이고 대표적인 그림 자극의 개발 및 보완이 필요하다. 둘째, 기존 도구에서는 만 2 세부 터 6세까지 1년 단위의 표준화 자료를 제공하였다면, 2 세 후반부터 7세까지 말소리 발달 시기의 전 연령대를 포함하고 특히 2 세 후반-4 세는 6 개월 단위로 구분, 말소리 초기발달단계를 세분화하여 보다 구체적이고 풍부한 자료를 제공할 필요성이 있다(Kim SJ, 2016; Lewis et al., 2015). 셋째, 기존의 서울 및 대구지역의 아동을 대상으 로 표집의 범위가 제한된 점을 보완하여 전국단위의 대규모 규준 을 구축함으로써 결과에 대하여 보다 타당한 정보를 제공할 필요 성이 있다(Jo \& Huh, 2017). 넷째, 단순한 단어수준의 검사를 넘어 서서 다음절 단어 및 문장 수준의 표준화를 보완.추가하여 보다 풍부한 말소리 발달의 정보를 구축할 필요성이 있다. 자발화 분석 은 보다 면밀하고도 자연스러운 아동의 말소리 산출에 관한 정보 를 줄 수 있으나 임상현장에서 적용하기에는 많은 시간과 노력이 소요된다는 한계점이 있다. 그러나 그림자료를 보고 목표문장을 유 도하거나 따라 말하게 하여 목표음소를 검사하는 것은 이에 대한 대안이 될 수 있다(Kim, 2016; Kim \& Shin, 2015). 자발화와 유사할 뿐 아니라, 문맥효과 관찰, 음소산출의 변이성 관찰, 오류의 심각도, 말 명료도를 포함한 여러가지 정보를 얻을 수 있으며, 특히 다음절 단어에 관한 아동의 산출능력을 분석함으로써 아동의 작업기억, 문해력 발달, 어휘, 문법능력과 관련한 정보를 얻을 수 있다(Barton-Hulsey, Sevcik, \& Romski, 2018; Kim \& Ha, 2014; Lewis et al., 2015; Masso, McLeod, Baker, \& McCormack, 2016; McNeill, Wolter, \& Gillon, 2017; Preston, Hull, \& Edwards, 2013; Seo, Ko, Oh, \& Kim, 2017; Waring, Eadie, Liow, \& Dodd, 2018). 다섯째, 보 다 다양한 말소리장애의 지표를 분석하고 각 지표 수치에 대한 표 준화작업을 실시하여 임상현장에서 중재계획을 세우는 데 실질적 인 도움을 줄 수 있을 것이다(Masso, Baker, McLeod, \& Wang, 2017; Preston et al., 2013).

이에 U-TAP의 제한점들을 보완한 U-TAP2가 개발되었는데 (Kim, Shin, Kim, \& Ha, in press), 이 개정판에서는 기존에 사용하 던 음소정확도와 음운변동 외에 phonological mean length of utterance (PMLU), proportion of whole-word proximity (PWP), proportion of whole-word correctness (PWC)와 같은, 음운 문헌에서 제안되고 있는 다양한 분석 지표들이 포함되었다(Ingram, 2002; Ingram \& Ingram, 2001; Seok, 2006; Yoon, Kim, \& Kim, 2013). 우
선 평균음운길이(PMLU)는 단어수준의 복잡성을 반영하는 지표 로서 아동이 산출한 단어의 분절음 수와 아동이 정확하게 산출한 자음의 수로 계산한다. 또한, 단어단위 근접률(PWP)은 아동이 목 표단어와 유사하게 산출한 정도를 보여주는 지표로 성인이 산출한 PMLU와 아동이 산출한 PMLU의 비율로 구할 수 있다. 단어단위 정확률(PWC)은 전체 단어 중에 정확하게 산출한 단어의 비율로 계산한다. U-TAP2에서는 이러한 지표들을 분석하기 위해 전산화 자동분석 프로그램(KSAT)을 개발하고 이와 연동하여 임상현장 에서 짧은 시간 안에 효율적인 평가결과를 정리하고 중재계획을 세 우는 데 보다 쉽고 간편하게 반영할 수 있도록 하였다. 본 연구에서 는 이러한 필요성과 개선사항을 반영하여 개발한 우리말 조음·음 운평가 2 검사도구의 타당도 및 신뢰도 검증을 실시하고자 하였다 (Kim, Song, Kim, \& Kim, 2018; Kim, Pae, \& Lee, 2005; Lee, Heo, \& Jang, 2015). 타당도 검증을 위해 내용타당도, 구인타당도, 공인 타당도, 발달적 타당도를 측정했으며(Kim, 2000), 신뢰도 검증을 위해 문항내적일치성, 반분신뢰도, 검사-재검사 신뢰도로 나누어 살펴보았다(Kim, Hong, \& Kim, 2009).

\section{연구방법}

\section{연구대상}

\section{표준화 규준을 위한 연구 대상}

U-TAP2 표준화 과정에는 만 2세 후반부터 7세까지 말소리 발달 시기에 해당하는 전 연령대의 아동이 참여하였다. 특히 2 세 후반에 서 5 세는 6 개월 단위로 구분하여 검사하였다. 전국 단위의 대규모 규준을 구축하기 위해 서울, 경기, 충청, 경상, 전라, 제주 등의 지역 에 거주하며, 수용·표현어휘력검사(REVT; Kim, Hong, Kim, Jang, \& Lee, 2009) 결과, 수용어휘력이 -2 SD 이상인 아동들을 대상으로 선정하였다. 검사 참여인원은 예비연구에 30명, 규준대상에 651명 이었으나 U-TAP2 자음정확도 검사 결과, 극단치(outliers)를 나타 낸 35 명을 제외하여 총 616 명을 선정하였다. 검사 대상자의 지역, 연 령 및 성별 분포는 Tables 1,2 와같다.

Table 1. Number of participants by region

\begin{tabular}{lc}
\hline Region & $\mathrm{N}(\%)$ \\
\hline Seoul \& Gyeonggi & $193(31.33)$ \\
Chungcheong & $98(15.91)$ \\
Gyeongsang & $148(24.03)$ \\
Jeolla & $157(25.49)$ \\
Jeju & $20(3.25)$ \\
Total & $616(100)$ \\
\hline
\end{tabular}


Table 2. Number of participants by age and gender

\begin{tabular}{lccc}
\hline Age group (yr;mo) & Male & Female & Total \\
\hline $2 ; 6-2 ; 11$ & 34 & 32 & 66 \\
$3 ; 0-3 ; 5$ & 37 & 32 & 59 \\
$3 ; 6-3 ; 11$ & 31 & 32 & 63 \\
$4 ; 0-4 ; 5$ & 41 & 42 & 83 \\
$4 ; 6-4 ; 11$ & 37 & 33 & 70 \\
$5 ; 0-5 ; 5$ & 29 & 33 & 62 \\
$5 ; 6-5 ; 11$ & 33 & 37 & 70 \\
$6 ; 0-6 ; 11$ & 45 & 49 & 94 \\
$7 ; 0-7 ; 11$ & 25 & 24 & 49 \\
Total & 302 & 314 & 616 \\
\hline
\end{tabular}

\section{신뢰도 및 타당도 연구를 위한 대상}

신뢰도 및 타당도 검증을 위한 참여자들은 다음과 같다. 우선, 타당도 검증을 위해서 언어치료학과 교수 13 명이 내용타당도 과정 에 참여하였고, 구인타당도 분석은 표준화수집에 참여한 616명, 전 체 아동의 자료가 사용되었으며, 공인타당도 검증을 위해서는 34 명의 아동들이 참여하였다. 또한 문항내적일치성 및 반분신뢰도 검 증을 위해서는 120 명의 아동이, 검사-재검사 신뢰도 검증을 위해 서는 41 명의 아동들이 참여하였다.

\section{검사 항목의 개발}

\section{단어수준 검사 항목}

단어 내의 어두초성, 어중초성, 어중종성, 어말종성의 네 위치에 서 우리말 19 개의 자음과 7 개의 단모음을 타당하게 평가할 수 있는 단어의 선정을 위해 다음과 같은 절차를 거쳤다(Kim, $\mathrm{Ha}, \mathrm{Kim}, \&$ Shin, 2018). 첫째, 53명의 언어치료학과 대학원생을 대상으로 기존 우리말 조음·음운평가의 단어에 대한 문항타당도 조사를 실시한 후 1 차 예비단어 45 개를 선정하였다. 둘째, 1 차 예비항목에 대한 예 비그림을 제작한 후 언어치료학과 학부생 52명을 대상으로 각 그림 에 대한 명명일치도(name agreement)를 조사하였다. 명명일치도 가 낮은 항목을 제외하고 30 문항으로 2 차 예비항목을 선정하였다. 셋째, 2 차 예비항목에 대해 말소리장애 전문가 13 명을 대상으로 전 문가(내용)타당도 평가를 실시하였다. 마지막으로 2차 예비항목에 대해 말소리장애 전공 교수 4 명을 대상으로 포커스 그룹인터뷰를 실시하였다. 인터뷰 결과를 바탕으로 3차 예비단어(후보항목 6개 포함) 34 개를 선정하였고, 예비실험을 실시하여 30 개의 최종항목 을 선정하였다. 단어수준 검사의 예는 Appendix 1 에 제시하였다.

\section{문장 수준 검사 항목}

후행하는 모음 문맥을 전설모음, 후고설 모음, 후저설 모음으로
다양하게 구성하여 모든 자음이 3 회 이상 산출되어 변이성과 문맥 의 영향을 관찰할 수 있도록 예비문장을 구성하였다(Kim et al., 2018). 이러한 예비문장에 대해 말소리장애 전공 교수 4 명을 대상 으로 포커스 그룹 인터뷰를 실시하였다. 인터뷰 결과를 바탕으로 2 차 예비문장을 선정하였고, 연구진과 전문가 1 명의 심층 토의를 거 쳐 최종적으로 11 개의 문장 항목을 선정하였다. 선정된 문장에 대 해 9명의 말소리장애 전문가를 통해 내용타당도 평가를 실시하였 다. 문장수준 검사의 예는 Appendix 1에 제시하였다.

\section{그림 제작}

단어와 문장 항목에 해당하는 그림을 전문가에게 의뢰하여 제 작한 후, 그림 시안에 대한 연구자 간의 토론, 100 여 명의 대학원생 들의 의견 수렴, 예비검사를 실시할 때 아동들의 반응 등을 반영하 여 여러 차례의 수정 과정을 거쳐 제작하였다(Kim et al., 2018). 그 림의 예는 Appendix 2에 제시하였다.

\section{검사 방법}

U-TAP2에서 단어수준 검사는 U-TAP과 마찬가지로 그림을 보 여준 다음 아동이 자발적으로 그림의 이름을 말하는 이름대기 과 제 방식이다. 문장수준 검사는 그림을 보여주고 4 어절 내외로 구성 된 문장을 들려준 후, 그대로 따라 말하게 하는 과제이다. 문장수준 의 검사는 3 세부터 실시하며, 문장자극을 제시할 때는 먼저 전체 문장을 1 회 들려주고 따라 말하도록 유도하였다. 하지만 아동이 전 체 문장을 따라 말하는 데 어려움이 있을 경우 2어절씩 끊어서 들 려줄 수 있다(Kim et al., 2018). 2어절씩 따라 말하기도 어려워할 경 우 3 세는 아동이 말한 자발화를 그대로 분석하고, 4 세 이상의 경우 에는 어절 단위로 끊어서 따라 말하게 하였다.

검사는 언어병리학을 전공하고 있는 대학원생이나 석사학위 소 지자에 의해 진행되었고, 검사자에게는 2 차에 걸쳐서 검사자 훈련 을 실시하였다. 1 차 훈련은 검사 내용에 대한 소개 및 실시 방법에 대한 강의로 이루어졌고, 2 차 훈련에서는 실제 검사를 실시한 후 질 문이나피드백을 받는 방식으로 진행되었다.

검사는 보호자의 동의를 받고 아동이 다니는 어린이집, 유치원 및 학교에서 대부분 진행하였고, 일부 아동은 가정을 직접 방문하 여 검사를 실시하였다. 검사는 대부분 1 회 방문을 통해 진행되었으 며, 아동의 주의력이나 건강 상태, 혹은 어린이집, 유치원 및 학교 일 정에 따라 2 회로 나눠 실시하기도 했다.

\section{검사의 실시 및 채점}

아동과 친밀감을 형성한 후, 검사자가 검사에 대해 소개하고, U- 
TAP, U-TAP2, 수용·표현어휘력검사(REVT-R) 등을 실시하였다. 반복으로 인한 학습효과를 감안하여 U-TAP과 U-TAP2 사이에 REVT-R 검사를 실시하였다.

모든 항목에 대한 아동의 반응을 기록지에 적고, 2 세 후반 아동 의 반응은 동영상으로 촬영하고, 3 세 이상 아동들은 녹음하여 일 주일 이내에 전사하여 전산화 자동분석 프로그램(KSAT)에 입력 한 후분석하였다.

전체 데이터 중 20 명의 자료를 무작위로 선택하여 석사과정에 재 학 중인 대학원생 2 명 간 신뢰도를 산출하였다. 실제 평가를 실시하 고, 발화자료 분석기준과 지침을 충분히 이해한 후에 단어 및 문장 수준에서 신뢰도 평가를 실시하였다. 평가자 간 신뢰도는 평가결과 가 일치한 항목 수를 전체 항목 수로 나눈 다음 100 을 곱해 환산하 였다. 그 결과, U-TAP2의 단어 및 문장 수준에서 조음정확도에 따 른 신뢰도는 $98 \%$ 로 나타났다.

\section{타당도 및 신뢰도 분석}

검사의 타당도를 검증하기 위해 내용타당도와 구인타당도, 그리 고 공인타당도 및 발달적 타당도를 분석하였다. 단어와 문장 검사 의 내용타당도를 살펴보기 위해 경력 10 년 이상의 말소리장애 분 야 전문가 또는 말소리장애 전공 교수 13 명에게 5 점 척도의 항목별 내용타당도 설문지를 배포 및 회수하여 분석하였다. 설문지는 5 점 척도 $(1$ 점 $=$ 전혀 그렇지 않다, 2 점 $=$ 그렇지 않다, 3 점 $=$ 보통이다, 4 점 $=$ 약간 그렇다, 5 점 $=$ 매우 그렇다)에 따라 내용의 적절성을 평가하여 단어 및 문장 검사의 평균값을 산출하여 검증하였다. 단어검사는 낱말 내 각 조음위치(어두초성, 어중초성, 어중종성, 어말종성)에서 조음방법(파열음, 마찰음, 파찰음, 비음, 유음)에 따라 음소들을 분 류하여 단어선정(30단어)에 대한 내용타당도를 평가하였고, 문장 검사는 전체 11 개 문장에 대한 5 가지 준거 질문을 통해 내용타당도 를 평가하였다.

구인타당도는 생활연령에 따라 2-5세(473명)와 6-7세(143명)의 2 집단으로 분류하여 각 집단 내 U-TAP2의 단어와 문장 수준에서 의 조음 및 음운 측정치 간의 상관분석을 통해 검증하였다. 단어수 준에서 목표음소 자음정확도(PCC)와 전체 자음정확도(total PCC), 평균음운길이(PMLU), 단어단위 정확률(PWC), 단어단위 근접률 (PWP)의 5 가지 측정치를 산출하고, 문장수준에서 total PCC와 $\mathrm{PMLU}, \mathrm{PWC}, \mathrm{PWP}$ 의 4 가지 측정치를 산출하여 전체 9 가지 조음 및 음운수치 간의 상관관계를 살펴보았다.

공인타당도는 서울 및 경기지역에 거주하는 34 명의 아동을 대상 으로 U-TAP과 U-TAP2의 단어 및 문장 수준에서 각 변수 간의 상 관계수를 산출하여 검증하였다. 단어수준에서 두 검사의 목표음
소 PCC와 total PCC, PMLU, PWC, PWP의 5가지 측정치 간의 상 관관계를 살펴보았고, 문장수준에서 두 검사의 total PCC와 PMLU, $\mathrm{PWC}, \mathrm{PWP}$ 의 4가지 측정치 간의 상관관계를 살펴보았다. 또한 연 령(6개 연령집단: 2;6-2;11세, 3세, 4세, 5세, 6세, 7세)에 따른 차이분 석을 통해 발달적 타당성을 분석하였다.

검사의 신뢰도는 검증하기 위해 문항내적일치성 신뢰도, 반분신 뢰도, 그리고 검사-재검사 신뢰도를 살펴보았다. 문항내적일치성 신뢰도는 각 지역에 거주하는 120 명의 아동을 생활연령에 따라 2-5세(59명)와 6-7세(61명)의 2집단으로 나누어 단어수준의 목표음 소 PCC와 문장수준의 전체 PCC에 관한 내적일관성을 Cronbach's $\alpha$ 를 통해 측정하였다.

반분신뢰도는 각 지역에 거주하는 120 명의 아동을 2-5세(59명) 와 6-7세(61명)의 2집단으로 나누어 Spearman-Brown의 공식에 따 라 단어 및 문장 수준의 PCC에 관한 반분신뢰도를 측정하였다.

검사-재검사 신뢰도는 서울 및 경기지역에 거주하는 2-7세의 아 동 41 명을 대상으로 1 차와 2 차에 걸쳐 동일검사자가 U-TAP2 검사 를 실시하여 두 검사결과 간의 상관계수를 산출하여 검증하였다. 1 차와 2 차 검사의 간격은 1 주에서 2 주 사이로 제한하였고, 2 세 아동 (1명)은 문장검사를 실시하지 않으므로 문장분석에서 제외하였다. 단어수준에서 1 차와 2 차 검사의 목표음소 PCC와 total PCC, PMLU, $\mathrm{PWC}, \mathrm{PWP}$ 의 5 가지 측정치 간의 상관관계를 살펴보았고, 문장수 준에서 1 차와 2 차 검사의 total PCC와 PMLU, PWC, PWP의 4 가지 측정치 간의 상관관계를 살펴보았다.

본 연구의 모든통계처리는 SPSS version 24 프로그램을 이용하였다.

\section{연구결과}

\section{타당도}

\section{내용타당도(content validity)}

U-TAP2의 각 문항들이 조음 및 음운을 평가하기에 적합한 내용 으로 구성되었는지를 확인하기 위하여 전문가 집단(13명)을 통한 내용타당도를 검증하였다. 단어검사에서 어두초성에 위치한 18 개 음소의 내용타당도는 평균 4.70 점, 어중초성의 17 개 음소는 평균 4.44점, 어중종성의 6개 음소는 평균 4.37점, 어말종성의 7 개 음소 는 4.56점으로 조음 및 음운을 검사하기 위해서 선정된 단어들이 모두 ‘약간 그렇다(전체평균 4.52점)'로 평가되었다(Figure 1). 문장 검사는 5 가지 준거 중 (1) '자극문장들에 목표음소들이 모두 포함 되어 있습니까?’라는 질문에 전문가 집단 모두 5점으로 '매우 그렇 다'로 평가하였고, (2) ‘모음문맥을 다양하게 하여 자극문장을 구성 하였습니까?'라는 질문에 평균 4.67점, (3) ‘자극문장들의 길이가 


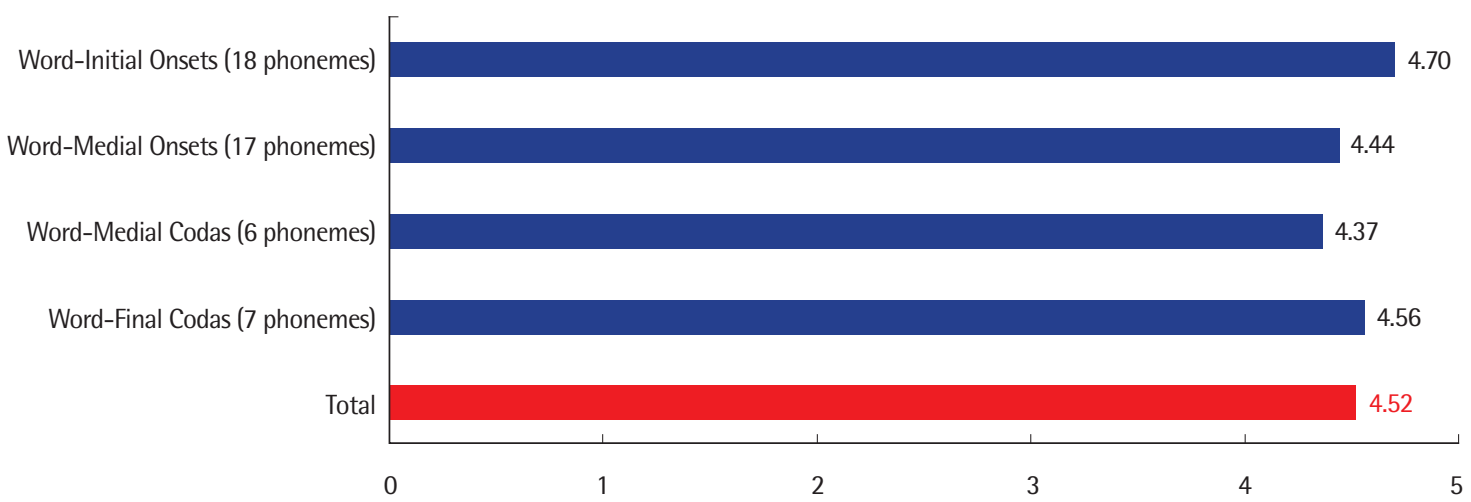

Figure 1. Content validity of word-level test in the Urimal Test of Articulation and Phonology-2 (U-TAP2).

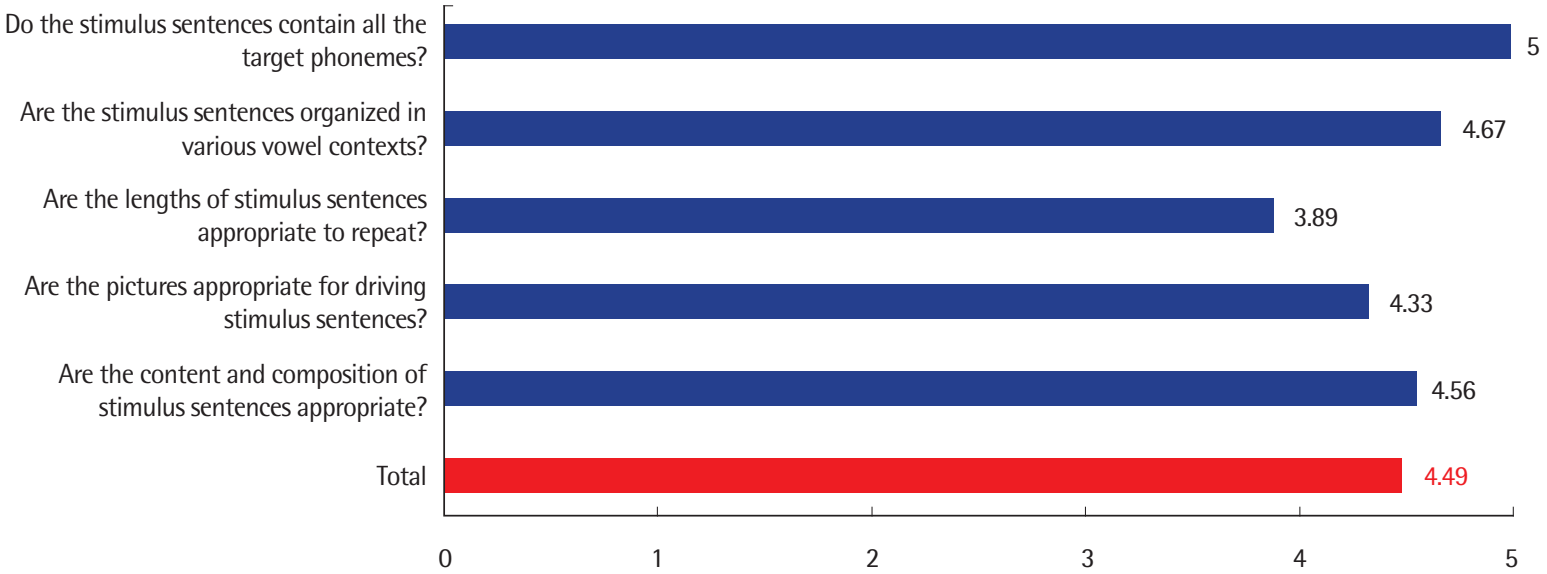

Figure 2. Content validity of sentence-level test in the Urimal Test of Articulation and Phonology-2 (U-TAP2).

Table 3. Correlations of U-TAP2 measures at word and sentence levels in the age groups 2-5 and 6-7 years

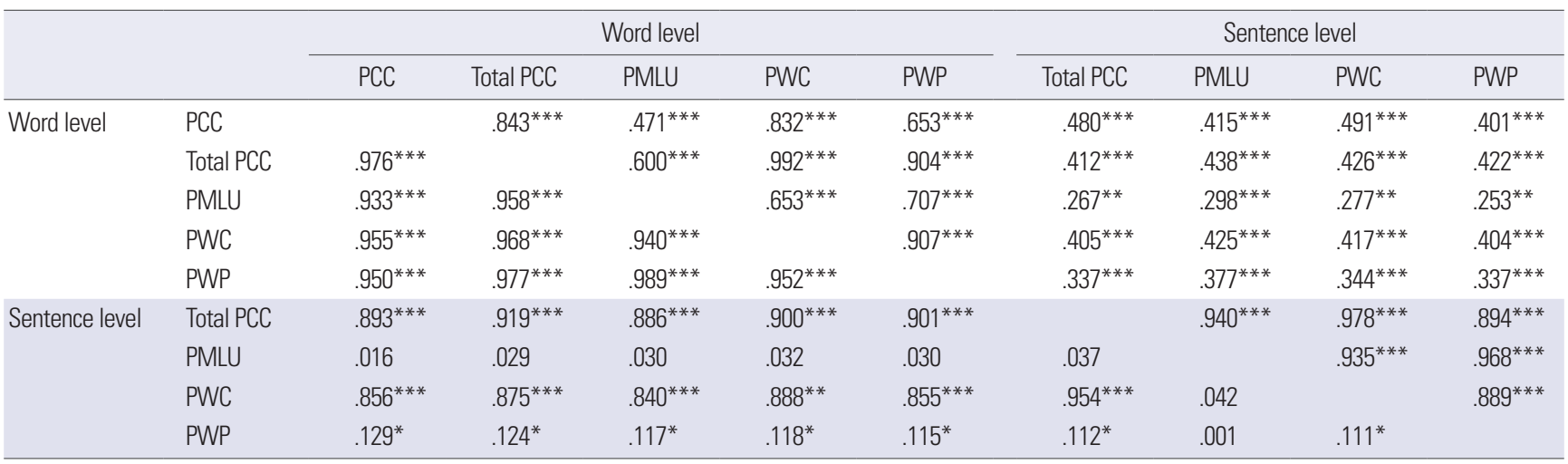

Coefficients below the diagonal represent correlations of U-TAP2 measures for the 2-5 age group ( $N=473$ ); coefficients above the diagonal represent correlations of U-TAP2 measures for the 6-7 age group ( $N=143)$.

U-TAP2 = Urimal Test of Articulation and Phonology-2; PCC= percentage of correct consonants; PMLU= phonological mean length of utterance; PWC= proportion of wholeword proximity; $P W P=$ proportion of whole-word correctness.

${ }^{*} p<.05,{ }^{* *} p<.01,{ }^{* * *} p<.001$. 
따라 말하기에 적절합니까?'라는 질문에 평균 3.89점, (4) ‘그림이 자극문장을 유도하기에 적절합니까?’라는 질문에 평균 4.33점, (5) '자극문장들의 내용과 구성이 적절합니까?'라는 질문에 평균 4.56 점을 나타내 문장수준에서 조음 및 음운을 검사하기 위하여 개발 된 문장들이 ‘약간 그렇다(전체평균 4.49점)’로 평가되었다(Figure 2).

\section{구인타당도(construct validity)}

구인타당도 검증 결과, 2-5세 아동의 경우, 단어수준의 목표음소 $\mathrm{PCC}$ 가 문장수준의 PMLU를 제외한 모든 단어 및 문장 측정치들 과 유의한 상관관계를 보였고 이 중 단어 측정치들과의 상관계수가 문장 측정치들과의 상관계수보다 높게 나타났다. 특히, 문장 PMLU 는 모든 단어 및 문장 측정치들과 유의한 상관을 보이지 않았고, 문 장 PWP는 문장 PMLU를 제외한 모든 측정치들과 유의한 상관을 보였으나 상관계수가 다른 값들보다 상대적으로 매우 낮았다. 6-7 세 아동의 경우, 단어수준의 목표음소 PCC가 단어 및 문장의 모든 측정치들과 유의한 상관관계를 보였으나 2-5세 집단보다 낮은 상 관을 나타냈다. 특히 문장 PMLU는 2-5세 집단과 달리 모든 측정치 들과 유의한 상관을 보였고, 문장 PWP 또한 모든 측정치들과 유의 한 상관을 보였으며 상관계수 또한 2-5세 집단보다 크게 증가하였 다. 2-5세와 6-7세 집단의 단어와 문장 수준에서의 조음 및 음운 측 정치들 간 상관분석 결과를 Table 3에 제시하였다.

Table 4. Correlations between U-TAP and U-TAP2 measures at word level $(\mathrm{N}=34)$

\begin{tabular}{llccccc}
\hline & & \multicolumn{4}{c}{ U-TAP2 } \\
\cline { 3 - 6 } & & PCC & Total PCC & PMLU & PWC & PWP \\
\hline U-TAP & PCC & $.954^{* * *}$ & $.946^{* * *}$ & $.913^{* * *}$ & $.927^{* * *}$ & $.918^{* * *}$ \\
& Total PCC & $.966^{* * *}$ & $.981^{* * *}$ & $.967^{* * *}$ & $.967^{* * *}$ & $.970^{* * *}$ \\
& PMLU & $.946^{* * *}$ & $.951^{* * *}$ & $.971^{* * *}$ & $.955^{* * *}$ & $.973^{* * *}$ \\
PWC & $.936^{* * *}$ & $.941^{* * *}$ & $.954^{* * *}$ & $.956^{* * *}$ & $.959^{* * *}$ \\
PWP & $.944^{* * *}$ & $.947^{* * *}$ & $.969^{* * *}$ & $.953^{* * *}$ & $.971^{* * *}$ \\
\hline
\end{tabular}

$\mathrm{U}-\mathrm{TAP}=$ Urimal Test of Articulation and Phonology; $\mathrm{PCC}=$ percentage of correct consonants; PMLU = phonological mean length of utterance; $P W C=$ proportion of whole-word proximity; PWP= proportion of whole-word correctness. ${ }^{* * *} p<.001$.

\section{공인타당도(concurrent validity)}

공인타당도 검증 결과, 단어수준에서 U-TAP과 U-TAP2의 모든 측정치들의 상관계수는 .90 이상으로 매우 높은 상관을 보였고, U-TAP의 total PCC가 목표음소 PCC보다 U-TAP2 측정치들과 높 은 상관을 보였다. 또한, 문장수준에서 U-TAP과 U-TAP 2의 측정 치들의 상관계수는 .70-.93로 모두 높은 상관을 보였으나 단어수준 과 비교하여 전체적으로 상관계수가 다소 감소하였다. 이 중 U-TAP 의 PWC와 U-TAP2 측정치들과의 상관계수가 가장 높게 감소하였 다. 단어와 문장수준에서 U-TAP과 U-TAP2의 조음 및 음운 측정 치 간의 상관분석 결과를 Tables 4, 5에 제시하였다.

발달적 타당도: 연령에 따른 차이 분석(age group analysis)

자음정확도(PCC)가 연령에 따라 차이를 나타내는지 살펴보기 위하여 단어와 문장 수준(2세 제외)의 PCC에 대하여 일원변량분 석을 실시하였으며, 분석 결과는 Table 6에 제시하였다. 일원변량분 석 결과, 단어와 문장 수준의 PCC는 연령에 따라 통계적으로 유의 한 차이를 나타냈다. 즉, 연령이 높아질수록 단어와 문장 수준의 PCC는 유의하게 증가한다고 볼 수 있다. Tukey에 의한 사후분석 을 실시한 결과, 단어수준에서는 발달적 집단이 4 개, 문장수준에 서는 3개로 형성되어 대체로 발달적 타당성을 나타내었다.

Table 5. Correlations between U-TAP and U-TAP2 measures at sentence level $(\mathrm{N}=34)$

\begin{tabular}{llllll}
\hline & & \multicolumn{4}{c}{ U-TAP2 } \\
\cline { 3 - 6 } & & Total PCC & PMLU & PWC & PWP \\
\hline U-TAP & Total PCC & $.894^{* * *}$ & $.881^{* * *}$ & $.873^{* * *}$ & $.863^{* * *}$ \\
& PMLU & $.917^{* * *}$ & $.926^{* * *}$ & $.887^{* * *}$ & $.912^{* * *}$ \\
& PWC & $.726^{* * *}$ & $.715^{* * *}$ & $.697^{* * *}$ & $.702^{* * *}$ \\
& PWP & $.921^{* * *}$ & $.927^{* * *}$ & $.886^{* * *}$ & $.911^{* * *}$ \\
\hline
\end{tabular}

U-TAP=Urimal Test of Articulation and Phonology; $P C C=$ percentage of correct consonants; $\mathrm{PMLU}=$ phonological mean length of utterance; $\mathrm{PWC}=$ proportion of whole-word proximity; PWP= proportion of whole-word correctness.

${ }^{* * *} p<.001$.

Table 6. Difference analysis by age

\begin{tabular}{|c|c|c|c|c|c|c|c|c|}
\hline & \multicolumn{6}{|c|}{ Age group (yr;mo) } & \multirow{2}{*}{$F$} & \multirow{2}{*}{ Post hoc } \\
\hline & $2 ; 6-2 ; 11$ & 3 & 4 & 5 & 6 & 7 & & \\
\hline Word level & $66(74.7)$ & $122(83.4)$ & $153(92.2)$ & 132 (97.9) & 93 (99.4) & $50(99.7)$ & $116.1^{* * *}$ & $2<3<4<5,6,7$ \\
\hline Sentence level & - & 102 (83.5) & $148(91.4)$ & 132 (97.2) & 92 (98.8) & $50(99.2)$ & $72.3^{* * *}$ & $3<4<5,6,7$ \\
\hline
\end{tabular}

Values are presented as number (\%).

${ }^{* * *} p<.001$. 
Table 7. Internal consistency reliability of items (Cronbach's $\alpha$ )

\begin{tabular}{lcc}
\hline & Aged 2-5 yr (N=59) & Aged 6-7 yr (N=61) \\
\hline Word-level PCC (30 items) & .873 & .886 \\
Sentence-level total PCC (11 items) & .965 & .973 \\
\hline
\end{tabular}

$\mathrm{PCC}=$ percentage of correct consonants.

Table 8. Split-half reliability (Spearman-Brown coefficient)

\begin{tabular}{lcc}
\hline & Aged 2-5 yr (N=59) & Aged 6-7 yr (N=61) \\
\hline Word-level PCC (30 items) & .874 & .870 \\
Sentence-level total PCC (11 items) & .981 & .972 \\
\hline
\end{tabular}

$\mathrm{PCC}=$ percentage of correct consonants.

\section{신뢰도}

문항내적일치성 신뢰도(internal consistency reliability)

문항내적일치성 신뢰도 검증 결과, 2-5세 아동의 경우, 단어수준 의 목표음소 PCC는 .87로 높은 내적일치도를 보였고, 문장수준의 전체 PCC는 단어수준의 PCC보다 상승한 값인 .97로 매우 높은 내 적일치도를 보였다. 6-7세 아동의 경우, 2-5세 집단과 동일한 형태로 단어수준의 목표음소 PCC가 .89로 높은 내적일치도를 보였고, 문 장수준의 전체 PCC도 단어수준의 PCC보다 상승한 값인 .97로 매 우 높은 내적일치도를 보였다. 또한, 6-7세 아동의 내적일치도는 2-5 세 집단과 비교하여 단어와 문장 PCC 모두 증가하였다. 두 집단의 단어수준의 목표음소 PCC와 문장수준의 전체 PPC의 문항내적일 치성 신뢰도를 Table 7에 제시하였다.

\section{반분신뢰도(split-half reliability)}

Spearman-Brown 공식에 의한 반분신뢰도를 산출한 결과, 2-5 세 아동의 경우, 단어수준의 목표음소 PCC는 .87로 높은 신뢰도를 보였고, 문장수준의 전체 PCC는 단어수준의 PCC보다 상승한 값 인 .98로 매우 높은 신뢰도를 보였다. 6-7세 아동의 경우, 2-5세 집단 과 동일한 형태로 단어수준의 목표음소 PCC가.87로 높은 신뢰도 를 보였고, 문장수준의 전체 PCC는 단어수준의 PCC보다 상승한 값인 .97로 매우 높은 신뢰도를 보였다. 그러나, 6-7세 아동의 반분 신뢰도는 2-5세 집단과 비교하여 단어와 문장 PCC 모두 감소하였 다. 두 집단의 단어수준의 목표음소 PCC와 문장수준의 전체 PPC 의 반분신뢰도를 Table 8 에 제시하였다.

\section{검사-재검사 신뢰도(test-retest reliability)}

검사결과의 시간적 변화에 따른 안정성을 분석하기 위해 검사재검사 신뢰도를 측정하였다. 그 결과, 단어수준에서 검사-재검사 상관계수는.89-.93으로 높은 상관관계를 보였고, 문장수준에서 검
Table 9. Test-retest reliability of U-TAP2 at word and sentence levels

\begin{tabular}{lccc}
\hline & Test & Retest & Correlation \\
\hline Word level (N=21) & & & \\
PCC & $97.02 \pm 6.90$ & $96.33 \pm 6.11$ & $.913^{* * *}$ \\
Total PCC & $96.86 \pm 6.84$ & $96.30 \pm 5.90$ & $.925^{* * *}$ \\
PMLU & $8.45 \pm .25$ & $8.42 \pm .22$ & $.899^{* * *}$ \\
PWC & $.92 \pm .15$ & $.90 \pm .14$ & $.920^{* * *}$ \\
PWP & $.99 \pm .30$ & $.98 \pm .03$ & $.885^{* * *}$ \\
Sentence level (N=20) & & & \\
Total PCC & $97.22 \pm 7.21$ & $97.60 \pm 5.18$ & $.926^{* * *}$ \\
PMLU & $10.76 \pm .30$ & $10.78 \pm .23$ & $.917^{* * *}$ \\
PWC & $.92 \pm .19$ & $.93 \pm .15$ & $.911^{* * *}$ \\
PWP & $.99 \pm .03$ & $.99 \pm .02$ & $.915^{* * *}$ \\
\hline
\end{tabular}

Values are presented as mean $\pm \mathrm{SD}$.

U-TAP2 = Urimal Test of Articulation and Phonology-2; PCC = percentage of correct consonants; $\mathrm{PMLU}=$ phonological mean length of utterance; $\mathrm{PWC}=$ proportion of whole-word proximity; PWP= proportion of whole-word correctness.

${ }^{* * *} p<.001$.

사-재검사의 상관계수 또한 .91-.93으로 높은 상관관계를 보였다. 단어와 문장 수준에서 U-TAP2의 검사-재검사 신뢰도를 Table 9에 제시하였다.

\section{논의 및 결론}

본 연구에서는 조음·음운능력의 발달 특성을 파악하고, 말소리 장애 아동을 선별 및 평가하는 것을 목적으로 개발한 우리말 조 음·음운평가-2 (U-TAP2) 도구의 타당도 및 신뢰도를 분석하였다. U-TAP2는 만 2세 후반에서 7세에 해당하는 아동을 대상으로 단 어 및 문장 수준에서 말소리의 산출능력을 평가하는 도구이다. 아 동의 말 산출을 유도하기 위해 단어수준에서는 자발화를, 문장수 준에서는 전체 문장이나 어절 단위로 따라 말하도록 하였다. 또한 산출된 말소리를 전사하여 전산화된 자동분석프로그램(KSAT)에 입력하면 조음음운능력의 주요 측정치인 평균음운길이, 단어단위 근접률, 단어단위 정확률, 자음정확도 등을 파악할 수 있으며, 생략 이나 대치 등에 의한 음운오류도 분석할 수 있다.

본 연구에서는 U-TAP2의 타당도를 검증하기 위해 내용타당도, 구인타당도, 공인타당도, 그리고 연령에 따른 발달적 타당도도 분 석하였다. 첫째, 내용타당도는 전문가 집단을 대상으로 설문지 방 법에 의해 측정하였으며, 전체 평균이 단어수준에서 4.52점, 문장 수준에서 4.49점으로 문항들의 타당한 정도가 '약간 그렇다'의 수 준을 보였다. 구인타당도는 U-TAP2의 단어와 문장수준에서의 조 음 및 음운 측정치 간의 상관분석을 통해 검증하였으며, 단어와 문 장 수준에서 자음정확도와 주요 측정치 간의 구인타당도는 2-5세 
집단에서 문장 PMLU를 제외한 모든 지표에서 유의한 수준으로 나타났다. 공인타당도는 U-TAP2와 U-TAP의 측정치 간에 단어수 준에서 .91-.98, 문장수준에서 .70-.93의 유의미한 상관을 보여 U$\mathrm{TAP} 2$ 의 타당도가 매우 높은 것으로 나타났다. 또한 연령에 따라 단어와 문장 수준의 자음정확도가 유의한 차이를 나타내 발달적 타당도가 있는 것으로 측정되었다. 단어와 문장 수준의 문항내적 일치성 신뢰도, 반분 신뢰도와 검사-재검사 신뢰도도 유의미하게 높은 것으로 평가되었다.

본 연구에서는 2-5세 집단의 문장수준에서 PCC와 PMLU, PWP 는 유의하지 않거나 유의하더라도 다른 지표에 비해 낮은 상관을 보였으나 6, 7세 집단에서는 모두 유의한 수준의 상관을 보이는 것 으로 나타났다. 이는 연령에 따른 조음의 개인차와 변이성으로 설 명해 볼 수 있을 것이다. 2-3세 아동 5명을 대상으로 자발화에서의 PCC와 단어단위 음운분석의 발달양상을 살펴본 종단연구에서는 이 연령대의 아동에게서 이미 3 세 후반에 약 $95 \%$ 의 자음정확도에 도달하는 것과는 달리 PMLU, PWP, PWC는 평균값이 5세 이후까 지도 점진적으로 발달하고 있으며 개인차가 큰 발달양상을 보였다 고 보고하였다(Park \& Yoon, 2016). 그러나 5-7세 아동을 대상으로 단어수준에서의 자음정확도와 단어단위 음운분석의 상관을 살펴 본 Park과 Son (2012)의 연구와 2세 아동을 대상으로 단어수준에 서의 자음정확도와 단어단위 음운분석을 살펴본 Park, Hwang과 Park (2011)의 연구에 의하면 PCC와 PMLU, PWP가 정적인 상관 을 나타낸다고 했다. 즉, 비교적 어린 연령대인 3세 전후에 숙달에 이르게 되는 PCC와는 달리 PMLU, PWP는 만 5세 전후까지도 지 속적인 발달이 이루어져 발달의 양상에서 차이가 있고, 단어수준 과 자발화와 같은 더 긴 측정단위에서의 어린 아동의 수행양상에 는 차이가 있음을 시사한다. 이와 관련하여 선행연구에서는 어린 연령일수록 발달의 개인차와 조음의 개별성을 고려하여 말소리 측 정지표를 다양하게 병행하여 실시할 것을 권유하고 있다(Park \& Son, 2012; Park \& Yoon, 2016; Seok, 2006).

본 연구에서는 기존의 연구와 마찬가지로 2세 후반-7세 집단에 서 단어와 문장 수준의 자음정확도가 연령에 따라 유의하게 차이 가 있는 것으로 나타났다(Park \& Son, 2012; Park \& Yoon, 2016; Ha $\&$ Hwang, 2013). 분석 결과, 단어수준의 자음정확도는 2 세 후반에 서 4 세까지는 평균 $8.75 \%$ 포인트, 4 세에서 5 세는 $5.7 \%$ 포인트, 5 세 에서 7세까지는 평균 $.9 \%$ 포인트 정도로 증가폭이 감소하긴 하지만 7세까지는 꾸준히 증가하는 것을 볼 수 있었다. 이러한 조음음운 발달의 추이는 아동의 말소리 산출을 조기에 평가하여 중재할 필 요성을 시사해 준다.

본 연구는 U-TAP2 개발을 위한 신뢰도 평가로 문항내적일치성
신뢰도와 반분신뢰도, 검사-재검사 신뢰도를 분석하였다. 문항내 적일치성 신뢰도는 단어검사의 대표 측정치인 목표음소 PCC와 문 장수준에서의 전체 PCC를 2-5세 아동과 6-7세 아동 집단으로 나 누어 살펴보았다. 그 결과, 모든 집단 연령에서 Cronbach's $\alpha$ 값이 .87 이상으로 높은 내적일치도를 보여 U-TAP2의 PCC 측정 항목 들의 신뢰성을 확보하였다. 이 중 문장의 전체 PCC가 단어의 목표 음소 PCC보다 높은 내적일치도를 보였는데 이는 목표음소만을 분 석 대상으로 하는 단어검사보다 전체음소를 분석 대상으로 하는 문장검사에서 아동의 조음 특성이 모두 반영된 결과로 유추해 볼 수 있다. 실제 아동의 조음 오류가 일관성 없이 나타나는 경우, 검사 에서 분석하고자 하는 목표음소가 아닌 다른 음소에서 오류가 나 타나면 오조음에도 불구하고 조음정확도 산출에 반영이 되지 않 기 때문이다. 또한, 6-7세 아동의 내적일치도가 2-5세 집단과 비교 하여 단어와 문장 PCC 모두 다소 증가하였는데, 이는 연령이 높아 질수록 아동의 조음 패턴이 점점 더 일관되고, 안정화되는 경향에 서 비롯된 것으로 사료된다.

반분신뢰도 또한 문항내적일치성 신뢰도와 마찬가지로 단어수 준의 목표음소 PCC와 문장수준의 전체 PCC를 2-5세 아동과 6-7 세 아동 집단으로 나누어 살펴보았다. 그 결과, 모든 집단 연령에서 Spearman-Brown 계수값이 .87 이상으로 높은 신뢰도를 보여줬다. 이 중 문장의 전체 PCC가 단어의 목표음소 PCC보다 높은 반분신 뢰도를 보여줬는데, 이는 문항내적일치성 신뢰도와 동일한 형태로 문장검사에서 아동의 조음 특성이 모두 반영된 결과라고 할 수 있 다. 반면, 6-7세 아동의 반분신뢰도가 2-5세 집단과 비교하여 단어 와 문장 PCC 모두 다소 감소하였는데 이는 문항내적일치성 신뢰도 와 상반된 결과이다. 그러나, 연령집단 간 반분신뢰도의 감소폭이 크지 않으므로(단어의 목표음소 PCC $=.004$; 문장의 전체 PCC= .009) 분석에 포함된 대상자들의 특성과 함께 반분신뢰도의 제한 점으로 양분하는 방법에 따라 신뢰도 계수가 달라진다는 점도 고 려될 수 있다. 검사-재검사 신뢰도는 연령 구분 없이 1 차와 2 차의 U$\mathrm{TAP} 2$ 검사에서 단어수준의 5가지 측정치(목표음소 PCC와 전체 $\mathrm{PCC}, \mathrm{PMLU}, \mathrm{PWC}, \mathrm{PWP}$ )와 문장수준의 4 가지 측정치(전체 PCC, $\mathrm{PMLU}, \mathrm{PWC}, \mathrm{PWP})$ 간의 상관관계를 살펴보았다. 분석 결과, 전반 적으로 . 89-.93의 높은 상관을 보였는데 이는 검사결과가 시간이 경 과되더라도 일관성 있게 나타나고 있음을 시사한다.

본 연구의 제한점 및 제언은 다음과 같다. 첫째, 본 연구에 참여 한 전체 피험자들을 연령별로 나누었을 때 대상자 수가 많지 않으 므로 보다 안정적인 표준화 규준을 위하여 추후에 연령별 대상자 수를 증가시킬 필요가 있다. 둘째, 본 연구에서 발달적 타당도를 제 외하고 연령 집단을 2-5세, 6-7세의 두 집단으로 분류하여 타당도 
및 신뢰도를 분석하였으므로 추후연구에서 연령 수준을 보다 세 분화하여 연령대별 결과를 살펴볼 필요가 있다. 셋째, U-TAP2의 문장검사에서 목표음소에 대한 조음평가가 이루어지지 않았므로 문장과 단어 수준의 비교 및 해석에 제한점이 있다. 이러한 이유로 문장에 대한 내용타당도 분석에서 전체문장 중 목표음소의 포함 여부만 준거 기준으로 제시할 수 있었으며, 문장에서 검사하고자 하는 특정 음소가 다른 음소들과 균등한 비율로 제시되었는지, 또 는 다양한 조음위치에서 구성되었는지에 관한 준거의 타당성을 평 가할 수 없었다. 따라서 추후연구에서 단어검사와 문장검사의 측정 치들을 통일시키기 위한 시도와 함께 이에 따른 타당도 및 신뢰도 검정이 다시 고려될 수 있다. 넷째, 본 연구의 발달적 타당도 및 문항 내적일치성 신뢰도, 반분신뢰도 검정에서 자음정확도만 분석하였 으므로 추후연구에서 다른 측정치들(PMLU, PWC, PWP)에 관해 서도 타당도 및 신뢰도를 분석할 필요가 있다. 마지막으로, 문항내 적일치성 신뢰도와 반분신뢰도의 연령 집단 간 차이 변화가 비록 낮은 수치이지만 서로 상반된 결과를 나타내므로 대상자 수를 증 가시켜 연령 변화에 따른 신뢰도 분석이 필요하다.

\section{REFERENCES}

Barton-Hulsey, A., Sevcik, R. A., \& Romski, M. (2018). The relationship between speech, language, and phonological awareness in preschool-age children with developmental disabilities. American Journal of Speech-Language Pathology, 27, 616-632.

Ha, S., \& Hwang, J. (2013). Speech measures from phonological analyses of spontaneous conversations in children between 18-47 months of age. Communication Sciences \& Disorders, 18, 425-434.

Ingram, D. (2002). The measurement of whole-word productions. Journal of Child Language, 29, 713-733.

Ingram, D., \& Ingram, K. D. (2001). A whole-word approach to phonological analysis and intervention. Language, Speech, and Hearing Services in Schools, $32,271-283$.

Jo, J. E., \& Huh, M. J. (2017). The phonological process characteristics of children between the ages of three and five. Journal of Speech-Language \& Hearing Disorders, 26, 1-8.

Kim, M. J. (2016). A literature review of articulation and phonological disorder assessments in Korea. Journal of Speech-Language \& Hearing Disorders, $25,11-22$.

Kim, M. J., Pae, S. Y., \& Lee, S. E. (2005). The development of the 'Test of Articulation for Children': concurrent validity. Korean Journal of Communi- cation \& Disorders, 10, 82-96.

Kim, N. Y., \& Ha, J. W. (2014). Phonological representations in children with articulation and phonological disorders. Communication Sciences \& Disorders, 19, 226-237.

Kim, S. J. (2016). Developing the 3 sentence screening test for speech sound disorders and prevalence in 6-year-old children. Communication Sciences « Disorders, 21, 580-589.

Kim, S. J., \& Lee, S. (2010). A comparison of Korean articulation tests for evaluation of phonological disorders. Special Education Research, 10, 343-359.

Kim, S. J., \& Shin, J. Y. (2015). Speech sound disorders. Seoul: Sigmapress.

Kim, S. J., Ha, J. W., Kim, Y. T., \& Shin, M. J. (2018). Developing the test Items of U-TAP2. Proceedings of the Korean Academy of Speech-Language Pathology and Audiology (KASA) Annual Conference, Gwangju, Korea.

Kim, Y. T. (2000). Validity analysis of the Preschool Receptive-Expressive Language Scale (PRES). Journal of Special Education, 35, 1-19.

Kim, Y. T., \& Shin, M. J. (2004). Urimal Test of Articulation and Phonology (U-TAP). Seoul: Hakjisa.

Kim, Y. T., Hong, K. H., \& Kim, K. H. (2009). Content and reliability analyses of the receptive and expressive vocabulary test (REVT). Korean Journal of Communication Disorders, 14, 34-45.

Kim, Y. T., Hong, K. H., Kim, K. H., Chang, H. S., \& Lee, J. Y. (2009). Receptive and Expressive Vocabulary Test (REVT). Seoul: Seoul Community Rehabilitation Center.

Kim, Y. T., Shin, M. J., \& Kim, S. J. (2014). Urimal Test of Articulation and Phonology (U-TAP) - revised edition. Seoul: Hakjisa.

Kim, Y. T., Shin, M. J., Kim, S. J., \& Ha, J. W. (in press). Urimal Test of Articulation and Phonology 2 (U-TAP 2). Seoul: Hakjisa.

Kim, Y. T., Song, S. H., Kim, J. A., \& Kim, H. C. (2018). Validity and reliability of Korean meta-pragmatic language assessment for children. Communication Sciences \& Disorders, 23, 94-108.

Lee, Y., Heo, H., \& Jang, S. (2015). Standardization of the language scale for school-aged children (LSSC). Communication Sciences \& Disorders, 20, 290-303.

Lewis, B. A., Freebairn, L., Tag, J., Ciesla, A. A., Iyengar, S. K., Stein, C. M., \& Taylor, H. G. (2015). Adolescent outcomes of children with early speech sound disorders with and without language impairment. American Journal of Speech-Language Pathology, 24, 150-163.

Masso, S., Baker, E., McLeod, S., \& Wang, C. (2017). Polysyllable speech accuracy and predictors of later literacy development in preschool children with speech sound disorders. Journal of Speech, Language, and Hearing 
Research, 60, 1877-1890.

Masso, S., McLeod, S., Baker, E., \& McCormack, J. (2016). Polysyllable productions in preschool children with speech sound disorders: error categories and the Framework of Polysyllable Maturity. International Journal of Speech-Language Pathology, 18, 272-287.

McNeill, B. C., Wolter, J., \& Gillon, G. T. (2017). A comparison of the metalinguistic performance and spelling development of children with inconsistent speech sound disorder and their age-matched and reading-matched peers. American Journal of Speech-Language Pathology, 26, 456-468.

Park, E. H., \& Yoon, M. S. (2016). Speech sound development of toddlers in spontaneous speech: segmental level and whole word level analysis. Korean Journal of Early Childhood Special Education, 16, 111-130.

Park, H. J., Hwang, H. J., \& Park, H. (2011). A study on phonological characteristics of two-years-old children by measures of whole-word. Journal of Speech-Language \& Hearing Disorders, 20, 123-135.

Park, H., \& Son, E. N. (2012). A study of the phonological characteristics of preschool children by measures of whole-words. Journal of Speech \& Hear- ing Disorders, 21, 19-34.

Preston, J. L., Hull, M., \& Edwards, M. L. (2013). Preschool speech error patterns predict articulation and phonological awareness outcomes in children with histories of speech sound disorders. American Journal of SpeechLanguage Pathology, 22, 173-184.

Seo, E. Y., Ko, Y. K., Oh, G. A., \& Kim, S. J. (2017). Phonological awareness and vocabulary characteristics of children with speech sound disorders. Communication Sciences \& Disorders, 22, 318-327.

Seok, D. I. (2006). A whole-word approach to phonological analysis with normal children aged from 3 to 5 years. Journal of Speech \& Hearing Disorders, $15,15-28$.

Waring, R., Eadie, P., Rickard Liow, S., \& Dodd, B. (2018). The phonological memory profile of preschool children who make atypical speech sound errors. Clinical Linguistics \& Phonetics, 32, 28-45.

Yoon, M. S., Kim, J. M., \& Kim, S. J. (2013). Phonological whole-word measures of spontaneous speech in children two to four years of age. Journal of Speech-Language \& Hearing Disorders, 22, 69-85. 
Appendix 1. Example items of the Urimal Test of Articulation and Phonology-2 (U-TAP2)

\begin{tabular}{ll}
\hline Word level & \multicolumn{1}{c}{ Sentence level } \\
\hline 꽃 & 자동차를 타고 동물원에 갔어요 \\
라면 & 창 밖으로 호랑이, 코뿔소가 보였어요 \\
김밥 & 풀밭에 돗자리를 쭉 깔았어요 \\
코끼리 & 가족들과 코끼리차 맨 뒤에 앉았어요 \\
해바라기 & 비빔밥, 수박, 팝콘을 먹었어요 \\
\hline
\end{tabular}

Appendix 2. Example pictures of the Urimal Test of Articulation and Phonology-2 (U-TAP2)

1. Word level
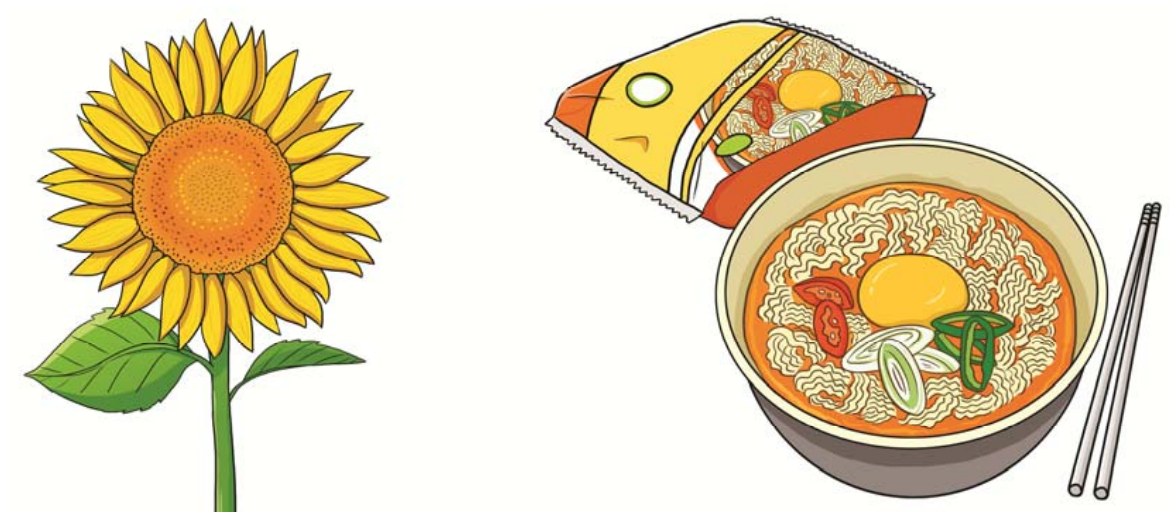

2. Sentence level

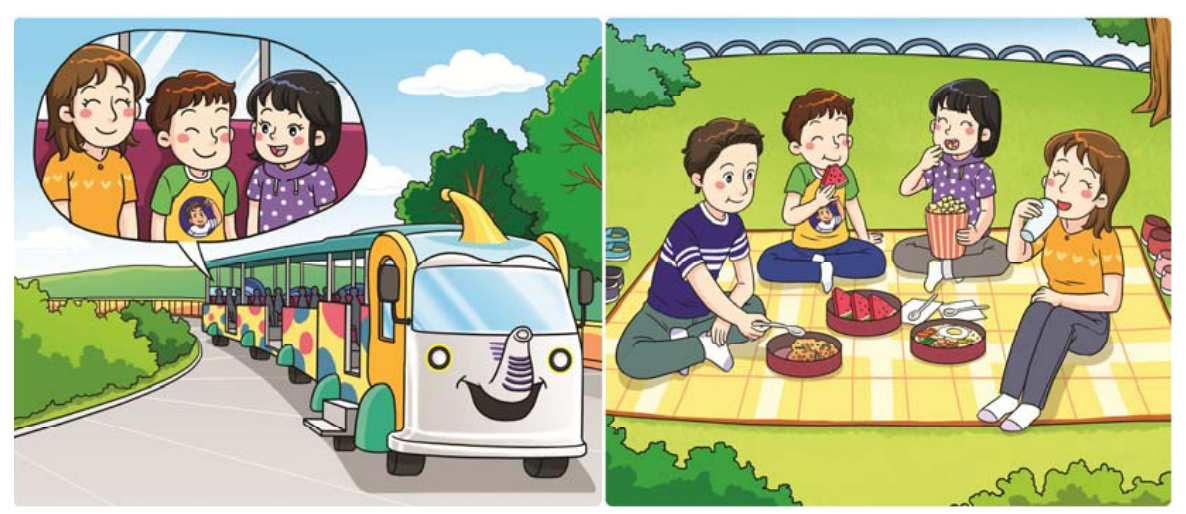




\section{국문초록}

\section{우리말 조음·음운평가-2 (U-TAP2) 개발을 위한 타당도 및 신뢰도 분석}

김영태'(교수, 제1저자, 교신저자) · 박희영'(박사후연구원) · 강진경'(학생) · 김정아'(학생) · 신문자(교수) · 김수진(교수) · 하지완(교수)

${ }^{1}$ 이화여자대학교 언어병리학과, ${ }^{2}$ 조선대학교 언어치료학과, ${ }^{3}$ 나사렛대학교 언어치료학과, ${ }^{4}$ 대구대학교 언어치료학과

배경 및 목적: 본 연구는 만 2 세 후반에서 7세 아동의 조음음운 능력을 평가하기 위해 현재 개발 중인 U-TAP2의 타당도 및 신뢰도를 분석하기 위한 것이다. 방법: 서울과 경기, 충청도, 경상도, 전라도, 제주도에 거주하는 아동 616 명(예비검사 30 명, 규준검사 616 명)을 대 상으로 U-TAP2 검사를 실시하였다. 타당도의 검증을 위해 내용타당도와 구인타당도, 공인타당도, 발달적 타당도를 평가하였고, 신뢰 도의 검증을 위해 문항내적일치성 신뢰도와 반분신뢰도, 검사-재검사 신뢰도를 평가하였다. 결과: 내용타당도는 단어수준에서 평균 4.52점, 문장수준에서 평균 4.49점으로 검사내용의 적절성이 '약간 그렇다'로 평가되었고, 단어와 문장 수준에서 자음정확도와 주요 측 정치 간의 구인타당도 또한 유의한 수준으로 나타났다. U-TAP2와 U-TAP1의 측정치 간에 유의미한 상관을 나타내 공인타당도가 높은 것으로 나타났으며, 연령에 따라 단어와 문장 수준의 자음정확도가 유의한 차이를 나타내 발달적 타당성이 있는 것으로 측정되었다. 단어와 문장 수준의 문항내적일치성 신뢰도, 반분신뢰도와 검사-재검사 신뢰도도 유의미하게 높은 것으로 평가되었다. 논의 및 결론: U-TAP2는 조음음운 능력을 평가하는 공식적인 검사도구로서 타당도와 신뢰도가 높은 편이며, 조음음운 능력의 발달적 특성 및 추이 를 파악하는 데 유용한 정보를 제공할수 있다.

핵심어: 조음 · 음운평가, U-TAP2, 타당도, 신뢰도

\section{참고문헌}

김나연, 하지완(2014). 조음음운장애아동과 일반아동의 음운표상의 질과음운부호화능력 비교. Communication Sciences \& Disorders, 19, 226-237. 김문정(2016). 조음음운장애평가에 관한 문헌 고찰. 언어치료연구, 26, 11-22.

김민정, 배소영, 이성은(2005). 아동용 조음검사의 개발: 공인타당도 검증. 언어청각장애연구, 10, 82-96.

김수진(2016). 말소리장애 선별검사 개발 및 6세 아동의 출현율 조사. Communication Sciences \& Disorders, 21, 580-589.

김수진, 신지영(2015). 말소리장애. 서울: 시그마프레스.

김수진, 이수향(2011). 음운장애 평가를 위한 한국어 말소리 검사 비교. 특수교육, 10,343-359

김수진, 하지완, 김영태, 신문자(2018). 우리말 조음·음운평가2 문항. 한국언어청각임상학회 학술대회 발표논문집.

김영태(2000). 취학전 아동의 수용언어 및 표현언어 척도(PRES)의 타당도 분석. 특수교육학연구, 35, 1-19.

김영태, 송승하, 김정아, 김효창(2018). 한국아동 메타-화용언어검사(KOPLAC)의 개발: 타당도와 신뢰도 분석. Communication Sciences \& Disorders, 23, 94-108.

김영태, 신문자(2004). 우리말 조음음운평가(U-TAP). 서울: 학지사.

김영태, 신문자, 김수진(2014). 우리말 조음음운평가(U-TAP): 수정판. 서울: 학지사.

김영태, 홍경훈, 김경희(2009). 수용-표현 어휘력검사의 개발연구: 문항개발 및 신뢰도 분석을 중심으로. 언어청각장애연구, 14, 34-45.

김영태, 홍경훈, 김경희, 장혜성, 이주연(2009). 수용·표현어휘력검사(REVT). 서울: 서울장애인종합복지관.

박은희, 윤미선(2016). 자발화에 나타난 2-3세 유아의 말소리 발달: 분절음과 단어 단위에서의 평가. 유아특수교육연구, 16, 111-130.

박현, 손은남(2012). 단어단위 음운 분석을 통한 취학 전 아동들의 음운 특성 연구. 언어치료연구, 21, 19-34.

박희정, 황하정, 박현(2011). 단어단위 음운분석을 통한 2세 아동의 음운특성 연구. 언어치료연구, 20, 123-135.

서은영, 고유경, 오경아, 김수진(2017). 말소리장애 아동의 음운인식과 어휘 특성. Communication Sciences \& Disorders, 22, 318-327.

석동일(2006). 단어단위 접근법에 의한 3-5세 유아의 음운특성 분석. 언어치료연구, 15, 15-28.

윤미선, 김수진, 김정미(2013). 자발화 문맥에서의 단어단위 음운 평가. 언어치료연구, 22, 69-85.

이윤경, 허현숙, 장승민(2015). 학령기 아동 언어 검사(LSSC) 표준화 연구. Communication Sciences \& Disorders, 20, 290-303.

조주은, 허명진(2017). $3,4,5$ 세 아동의 음운변동 특성. 언어치료연구, 26, 1-8.

하승희, 황진경(2013). 18-47개월 아동의 자발화 분석에 기초한 말소리 측정치에 관한 연구. Communication Sciences \& Disorders, 18, 425-434. 